\begin{tabular}{|l|l|l||}
\hline \multicolumn{2}{|c|}{ PublisherInfo } \\
\hline \hline PublisherName & $:$ & BioMed Central \\
\hline \hline PublisherLocation & $:$ & London \\
\hline \hline PublisherImprintName & $:$ & BioMed Central \\
\hline \hline
\end{tabular}

\title{
Markers of tumor endothelium-Implications for anti-angiogenic therapies
}

\begin{tabular}{|l|l|l||}
\hline \multicolumn{2}{|c||}{ ArticleInfo } \\
\hline \hline ArticleID & $:$ & 141 \\
\hline \hline ArticleDOI & $:$ & $10.1186 /$ ar-2000-66855 \\
\hline \hline ArticleCitationID & $:$ & 66855 \\
\hline \hline ArticleSequenceNumber & $:$ & 98 \\
\hline \hline ArticleCategory & $:$ & Paper Report \\
\hline ArticleFirstPage & $:$ & 1 \\
\hline \hline ArticleLastPage & $:$ & 3 \\
\hline \hline & $:$ & RegistrationDate : 2000-10-13 \\
ArticleHistory & $:$ & OnlineDate \\
\hline \hline ArticleCopyright & $:$ & Current Science Ltd2000-10-13 \\
\hline \hline ArticleGrants & $:$ & \\
\hline \hline ArticleContext & $:$ & 130753311 \\
\hline \hline
\end{tabular}




\section{Keywords}

Angiogenesis, endothelial cells, differential gene expression, tumors

\section{Context}

Tumors require a sufficient blood supply for their expansive growth. The aim of this study was to identify tumor-specific endothelial markers that might be candidates for a specific anti-angiogenic tumor therapy.

\section{Significant findings}

In total 79 genes were identified that were differentially expressed between endothelial cells derived from tumor endothelium and normal colonic mucosa. The expression of 33 of these genes was elevated at least 10 -fold in tumor endothelial cells, including 11 known and 14 so-far uncharacterized genes. In situ hybridization on tissue samples confirmed that the expression of eight of the nine uncharacterized genes that were studied in depth were specific for tumor endothelial cells. Moreover, these genes were also expressed on endothelial cells of other tumors including lung and brain tumors. Except for one gene, these genes were also expressed at elevated levels in other angiogenic states such as healing wounds.

\section{Comments}

In this landmark paper several new markers were identified that differ between normal blood vessels and newly formed vessels of tumors. The authors had to overcome the serious technical problem of isolating pure endothelial cells from tissues, which was solved by using positive and negative selection with magnetic beads. Differential gene expression was examined using a modified SAGE technique that was developed in the same laboratory some years ago (see Additional information). This technique allows the analysis of cells that only constitute a small fraction in the tissue under study. Unfortunately, virtually all genes expressed on tumor endothelial cells were also found on endothelial cells of other 
non-neoplastic angiogenic states such as wound healing, which could be a serious problem for antiangiogenic drug-development. The synovium of patients with rheumatoid arthritis, another example of a disease with an increased neoangiogenesis, was not examined.

\section{Methods}

Magnetic beads, RT-PCR, serial analysis of gene expression (SAGE), in situ hybridization, immunochemistry

\section{Additional information}

Velculescu VE Zhang L Vogelstein B Kinzler KW: http://www.sagenet.org/sage_protocol.htm Science 1995, 270:484-487 (PubMed abstract).

\section{References}

1. St Croix B, Rago C, Velculescu V, Traverso G, Romans KE, Montgomery E, Lal A, Riggins GJ, Lengauer C, Vogelstein B, Kinzler KW: Genes expressed in human tumor endothelium. Science. 2000, 289: 1197-1202.

This PDF file was created after publication. 